https://doi.org/10.18778/7525-913-1.10

MAŁGORZATA PACHOWICZ*

\title{
O zmianach w systemie polskiej edukacji na łamach „Dziennika Polskiego” (z lat 1956-1961)
}

Lata 1956-1961 w historii polskiego szkolnictwa to okres ważnych przemian w systemie polskiej edukacji. Dotyczyły one właściwie wszystkich poziomów nauczania - od szkolnictwa podstawowego do wyższego - i były wprowadzane poprzez odpowiednie akty prawne, istotne dla funkcjonowania polskiego systemu szkolnego.

Dekret z dnia 23 marca 1956 r. o obowiązku szkolnym (ze zmianami wynikającymi z art. 43 ustawy o rozwoju systemu oświaty i wychowania) ${ }^{1}$ usankcjonował powszechne i obowiązkowe kształcenie młodzieży (w wieku od 7 do 16 lat) w zakresie ośmiu klas szkoły podstawowej. Z kolei ustawa z dnia 10 września 1956 r. o przejęciu szkolnictwa zawodowego przez ministra oświaty² łączyła to szkolnictwo

* Dr, Zakład Filologii Polskiej, Instytut Humanistyczny, Państwowa Wyższa Szkoła Zawodowa w Tarnowie, 33-100 Tarnów, ul. Mickiewicza 8.

1 Dz. U. 1956, nr 9, poz. 52.

2 Dz. U. 1956, nr 41, poz. 186. Koordynacją spraw kształcenia zawodowego od 1949 r. zajmował się Centralny Urząd Szkolenia Zawodowego (CUSZ), powołany na mocy rozporządzenia Rady Ministrów z dnia 21 czerwca 1949 r. (Dz. U. 1949, nr 40, poz. 283). Do jego zadań należało m.in. „przygotowanie dla podstawowych gałęzi gospodarki narodowej kadr, niezbędnych do wykonania zadań określonych przez narodowe plany gospodarcze i zabezpieczenie prawidłowego podziału tych kadr pomiędzy poszczególne gałęzie gospodarki narodowej. [...] Do zakresu działania Centralnego Urzędu Szkolenia Zawodowego należą sprawy szkolenia i przysposobienia zawodowego dla potrzeb przemysłu, rękodzieła i handlu"; Organizacja i funkcjonowanie współczesnych systemów edukacyjnych, cz. II: Organizacja systemu edukacyjnego w Polsce w latach 1932-1993. Antologia dokumentów i materiałów, wybór i oprac. T. Gumuła, J. Krasuski, S. Majewski, Kielce 1994, s. 139. CUSZ został zniesiony ustawą z dnia 10 września 1956 r., a sprawy szkolnictwa zawodowego przekazano ministrowi oświaty - tamże, s. 175. Por. także: A. O r c zy k, Zarys historii szkolnictwa i myśli pedagogicznej, Warszawa 2008; M. P ę c h e r s k i, M. Ś w i ą t e k, Organizacja oświaty w Polsce w latach 1917-1977. Podstawowe akty prawne, Warszawa 1978; T. W i l o c h, Ustrój szkolny, Warszawa 1973. 
z całym systemem edukacji. Od roku 1958 w większości techników i innych średnich szkołach zawodowych nauka trwała 5 lat, natomiast w zasadniczych szkołach zawodowych - 3 lata.

Reforma szkolna wprowadzona ustawą z dnia 15 lipca 1961 r. o rozwoju systemu oświaty i wychowania ${ }^{3}$ utrzymała obowiązek szkolny dla uczniów w wieku od 7 do 17 lat. Podstawą systemu kształcenia i wychowania stała się jednolita programowo, powszechnie obowiązująca, 8-klasowa szkoła podstawowa. Na jej podbudowie zostały oparte 4-letnie licea ogólnokształcące; 4- lub 5-letnie licea i technika zawodowe (kończące się egzaminem dojrzałości uprawniającym - podobnie jak w liceach ogólnokształcących - do ubiegania się o przyjęcie do szkół wyższych); 2- lub 3-letnie zasadnicze szkoły zawodowe (absolwenci tych szkół mogli kształcić się dalej w szkołach średnich ogólnokształcących i zawodowych). Ustawa o szkolnictwie wyższym przyjęta 5 listopada 1958 r. ${ }^{4}$ dawała swobodę twórczych badań, zliberalizowała dyscyplinę studiów i zwiększała rolę organów wybieralnych (senatu i rad wydziałów) ${ }^{5}$. Jednym z podstawowych zadań szkół wyższych było „[...] kształcenie i wychowywanie kadr wysoko kwalifikowanej inteligencji zawodowej, przygotowanej do wykonywania zawodów wymagających naukowego opanowania określonej dziedziny wiedzy [...]”.

Problemy polskiego szkolnictwa, reformy systemu edukacji w latach 19561961 były obecne na łamach „Dziennika Polskiego”, gazety codziennej wydawanej w Krakowie i obejmującej swym zasięgiem region Małopolski ${ }^{7}$. Zamieszczone w gazecie i wybrane teksty prasowe (informacyjne i publicystyczne) z tego okresu, dotyczące zagadnień szkolnictwa, stanowią podstawę materiałową przedstawianych rozważań. W publikacjach prasowych z lat 1956-1961 omawiano bowiem zmiany strukturalne i programowe w polskiej edukacji oraz zastanawiano się nad rolą szkoły i nauczycieli w kontekście dokonujących się przemian. Te kwestie przedstawiano albo rozdzielnie albo łącznie, podkreślając znaczenie i konieczność wprowadzenia reform w polskim szkolnictwie różnych szczebli w zmieniającej się rzeczywistości.

\section{Zmiany strukturalne i programowe w systemie polskiej oświaty}

Za zapowiedź przygotowywanych zmian w polskim szkolnictwie można uznać felieton zamieszczony w „Dzienniku Polskim” w związku z rozpoczęciem nowego roku szkolnego 1956/1957. W opublikowanym tekście znalazły się m.in. takie słowa:

${ }^{3}$ Dz. U. 1961, nr 32, poz. 160.

4 Tekst ustawy opublikowano w: Dz. U. 1958, nr 68, poz. 336; natomiast w Dz. U. 1965, nr 16, poz. 114 znalazło się Obwieszczenie Ministra Szkolnictwa Wyższego z dnia 15 kwietnia 1965 r. w sprawie ogłoszenia jednolitego tekstu ustawy z dnia 5 listopada 1958 r. o szkolnictwie wyższym.

5 A. L. S o w a, Od Drugiej do Trzeciej Rzeczpospolitej (1945-2001), t. 10: Wielka historia Polski, Kraków 2001, s. 223.

6 Ustawa z dnia 5 listopada 1958 r. o szkolnictwie wyższym, Dz. U. 1958, nr 68, poz. 336.

7 Media. Leksykon PWN, red. E. Banaszkiewicz-Zygmunt, Warszawa 2000, s. 53. 
Niech młodzi będą coraz mądrzejsi. Lepiej poprowadzą kraj i świat po drodze postępu. Trzeba nam coraz bardziej wykształconych i kulturalnych ludzi o szerokich horyzontach wiedzy. Czeka na nich przemysł, gospodarka - plan pięcioletni i dużo następnych. Niech tylko młodzi się uczą ${ }^{8}$.

To zreformowana szkoła powinna więc wykształcić młodych ludzi i właściwie przygotować ich do wykonywania różnych zawodów, zatem przeobrażenia w polskim szkolnictwie są konieczne.

Z kolei 1 września 1956 r. zamieszczono relację z konferencji nauczycieli szkół zawodowych okręgu krakowskiego ${ }^{9}$. Podczas dwudniowego spotkania pod koniec sierpnia 1956 r. nauczyciele dyskutowali nad tym, w jaki sposób należy przygotować młodzież do wykonywania przez nią w przyszłości wybranego zawodu.

Poddano ostrej krytyce dotychczasowy schematyczny system nauczania. Najwięcej miejsca poświęcono nauczaniu przedmiotów zawodowych, wiadomo bowiem, że zakres wiadomości absolwentów zasadniczych szkół zawodowych nie zawsze odpowiada wymogom stawianym im w pracy jako wykwalifikowanym pracownikom. Winę za to ponosi przede wszystkim szkoła i personel nauczycielski, który nie potrafi przygotować należycie ucznia do zawodu. Oprócz wykładów teoretycznych uczniowie szkół zawodowych dużą część zajęć szkolnych odbywają w warsztatach przyszkolnych lub w zakładach pracy. Niestety warsztaty przyszkolne mają przeważnie przestarzałe maszyny i urządzenia, dlatego uczniowie nie mają możności zapoznać się z najnowocześniejszymi osiągnięciami techniki, co odbija się w ich późniejszej pracy. Poza tym bardzo często w warsztatach brak jest odpowiednich surowców potrzebnych do ćwiczeń praktycznych ${ }^{10}$.

Podczas tego spotkania wypowiadano się również na temat nauczania przedmiotów ogólnych, oceniając, że „wprost katastrofalnie przedstawia się sytuacja, jeśli chodzi o naukę języka polskiego, historii i literatury polskiej"11. Nauczyciele zapoznali się również z projektem ustawy o przejęciu szkolnictwa zawodowego przez Ministerstwo Oświaty.

W październiku 1956 r. w „Dzienniku Polskim” opublikowano krótką notatkę zatytułowaną Nowe projekty struktury szkolnictwa ${ }^{12}$, w której znalazła się informacja o posiedzeniu głównej komisji szkolno-pedagogicznej przy Związku Zawodowym Nauczycielstwa Polskiego. Podczas spotkania omawiano projekt przyszłej struktury polskiego szkolnictwa, czyli zastąpienia istniejącej 7-letniej szkoły podstawowej - 10-letnią. Po jej ukończeniu młodzież mogłaby kontynuować naukę w szkołach zawodowych lub w dwuletnich liceach ogólnokształcących przygotowujących do studiów wyższych. Uczestnicy spotkania opowiedzieli się również za zmianami w systemie kształcenia nauczycieli, które polegałyby na likwidacji liceów pedagogicznych i zastąpieniu ich trzyletnimi instytutami nauczycielskimi.

W rozpoczynającym się roku szkolnym 1957/1958 wprowadzono nowe programy nauczania i nowe podręczniki do wielu przedmiotów. W „Dzienniku

8 Powitanie szkoły, „Dziennik Polski” [dalej: DP] 1956, nr 210, s. 5.

${ }^{9}$ (s), W nowym roku szkolnym poziom nauki w szkołach zawodowych musi być podniesiony!, DP 1956, nr 209, s. 4.

10 Tamże.

11 Tamże.

12 Nowe projekty struktury szkolnictwa, DP 1956, nr 250, s. 1. 
Polskim” tę informację opatrzono komentarzem, że to „stawia przed naszymi wychowawcami szczególnie trudne zadania i dodatkowe obowiązki"13.

Kwestie zmian w polskim szkolnictwie znalazły się również w otwierającym nowy rok szkolny 1958/1959 przemówieniu ministra oświaty Władysława Bieńkowskiego, który stwierdził, że „rok szkolny rozpoczyna całe społeczeństwo, [...] nie ma bowiem takiej dziedziny życia, która by bezpośrednio nie wiązała się ze sprawą szkoły, ze sprawą kształcenia"14. Niezwykle ważne staje się zatem „wzmożenie społecznego wysiłku w dziedzinie budownictwa szkolnego"15, ale jeszcze ważniejsze - „podniesienie poziomu pracy szkół. Poprawa wyników nauczania musi iść w parze z udoskonaleniem pracy wychowawczej"16.

Rok akademicki 1958/1959 przyniósł z kolei nową ustawę o szkolnictwie wyższym, „zmiany w systemie stypendialnym, podniesienie na wyższy poziom pracy wychowawczej w uczelniach, wzmocnienie dyscypliny studiów"17. Te kwestie poruszył premier Józef Cyrankiewicz w przemówieniu skierowanym do studentów UJ ${ }^{18}$, biorąc udział wraz z ministrem szkolnictwa wyższego Stefanem Żółkiewskim i wicemarszałkiem sejmu Jerzym Jodłowskim w inauguracji roku akademickiego w Uniwersytecie Jagiellońskim. Odwołując się do ustaleń, jakie zapadły podczas partyjnej narady działaczy oświatowych pod przewodnictwem Władysława Gomułki, a dotyczących spraw ustrojowych szkolnictwa niższego, podkreślił że „Polska Rzeczpospolita Ludowa z większym niż kiedykolwiek zrozumieniem odnosi się do nauki i jej potrzeb. [...] Szkoła wyższa musi otwierać przed studentem współczesne horyzonty ideowe"19. Premier odniósł się także do rządowego projektu ustawy o szkolnictwie wyższym, mówiąc, iż został on złożony w Sejmie. Zwrócił uwagę, że nowa ustawa „zapewnia właściwy wpływ władzy ludowej na kierunek rozwojowy wyższych uczelni, potwierdza wypróbowane w dwuletnim doświadczeniu formy bezpośredniego zarządzania szkołami przez obieralnych rektorów i dziekanów oraz wzmacnia zasady decydowania przez kolektywne ciało szkolne o sprawach wewnętrznych uczelni, o szczegółowych programach, kadrach asystenckich, o nadawaniu stopni doktorskich i przeprowadzaniu przewodów habilitacyjnych"20.

Rok szkolny 1960/1961 poprzedzał wprowadzenie reformy systemu oświatowego. Był to okres podsumowań i analizy dotychczasowych osiągnięć: „Ostatnie lata w szkolnictwie charakteryzowały się stałym podnoszeniem stopnia organizacyjnego szkół podstawowych, dużym rozwojem szkolnictwa zawodowego, po-

${ }^{13}$ (n), Witaj szkoło!, DP 1957, nr 208, s. 8.

${ }_{14}$ Ponad $4 \mathrm{mln}$ dzieci zasiada na ławie szkolnej. Nowy rok szkolny rozpoczęty. Przemówienie radiowe ministra Bieńkowskiego, DP 1958, nr 208, s. 1.

${ }^{15}$ Tamże, s. 2.

16 Tamże.

17 Wyższe uczelnie wkroczyły w nowy rok. Przemówienie Józefa Cyrankiewicza do młodzieży akademickiej, DP 1958, nr 234, s. 1.

${ }^{18}$ Zasadniczą płaszczyzną zbliżenia wyższych uczelni do życia jest oparcie nauki i praktyki badawczej o ideologię socjalistyczną. Przemówienie premiera J. Cyrankiewicza do studentów, DP 1958, nr 234, s. 4.

19 Tamże.

20 Tamże. 
ważnymi wkładami inwestycyjnymi w budownictwo szkół, a także zwiększeniem się kadry nauczycielskiej i podnoszeniem stopnia jej kwalifikacji"21. Był to także rok, w którym Ministerstwo Oświaty podjęło próby pewnych reform dotyczące m.in. „zbliżenia szkoły do życia”22 poprzez zmianę treści oraz metod pracy zmierzających do wprowadzenia nowego systemu szkolnego. Do pracowników nauki, studentów i administracji wyższych uczelni Krakowa zwrócił się I sekretarz KW PZPR w Krakowie, Lucjan Motyka. Stwierdził, że „wychowankowie uczelni wyższych muszą być ludźmi światłymi i postępowymi, którzy będą uczuciowo zaangażowani w wykonywaniu zadań, jakie stoją przed narodem w związku z koniecznością odrobienia wynikających z przeszłości, a dziedziczonych strat i zaniedbań oraz spełnienia społecznych, ekonomicznych i kulturalnych zamierzeń w budownictwie socjalistycznym"23.

Wprowadzenie reformy oświaty poprzedzały działania nie tylko ministerstwa, lecz także władz lokalnych. W Krakowie 19 czerwca 1961 r. zebrało się Plenum Komitetu Miejskiego PZPR ${ }^{24}$, a głównym tematem posiedzenia była analiza liczby i typów szkół (podstawowych, liceów i techników zawodowych, zasadniczych szkół zawodowych, szkół mistrzów) na terenie miasta. Stwierdzono, że „w wyniku [...] prac Kuratoryjnej Komisji i jej zespołów roboczych opracowano już sieć szkół 8-klasowych, ustalając, iż do r. 1967 ilość ich z 82 wzrośnie do 116, przy czym 115 będzie 8-klasowych, jedna zaś tylko niepełna"25.

O reformie systemu oświatowego „Dziennik Polski” poinformował czytelników w lipcu 1961 r., zamieszczając na pierwszej stronie obszerną informację o uchwaleniu ustawy przez Sejm ${ }^{26}$. Posłowie wypowiadający się w debacie na temat zmian w szkolnictwie byli zgodni, że ustawa będzie miała ogromne znaczenie dla podniesienia poziomu oświaty w Polsce; wskazywali, że „ustawa stawia sobie niezwykle ambitne cele, których realizacja wymagać będzie wiele wysiłku"27, zwracali uwagę na nowe i trudne obowiązki, jakich podejmą się nauczyciele i wychowawcy, apelowali „do władz państwowych o zwiększenie opieki nad nauczycielstwem, przede wszystkim na wsi"28. Podkreślali również, że ustawa sankcjonuje świeckość szkoły, gdyż „historia współczesnej epoki idzie drogą socjalizmu opartego na naukowych podstawach marksistowsko-leninowskich. $\mathrm{Na}$ tej drodze rozwija się nasz kraj i [...] na tej drodze działa i działać będzie szkoła polska"29. Sejm uchwalił ustawę przy 5 głosach wstrzymujących się.

${ }^{21}$ M. Krupowa, Rozmowa z wiceprezesem Zarządu Głównego ZNP. Wychowankowie $i$ wychowawcy, DP 1960, nr 208, s. 3.

22 Tamże.

23 Przed nowym rokiem akademickim. Życzenia KW PZPR, DP 1960, nr 234, s. 1.

${ }^{24}$ (kr), Kraków ma dobre warunki realizacji reformy oświatowej. Pogłębienie działalności wychowawczej wymaga pracy nad kadrą nauczycielską, DP 1961, nr 144, s. 1.

25 Tamże. Autor tej publikacji zwrócił także uwagę na fakt, że „sprawność szkół, która w skali krajowej wynosi w szkolnictwie podstawowym 53,8\%., w Krakowie osiąga poziom 78,3\%, stawiając nas na pierwszym miejscu w Polsce".

26 Uchwalenie ustawy o reformie oświaty. Wiosenna sesja Sejmu zamknięta, DP 1961, nr 167, s. 1.

27 Tamże.

28 Tamże.

29 Tamże. 


\section{Misja szkoły i nauczycielstwa w kontekście zmian w systemie oświaty}

W dyskusjach dotyczących zmian wprowadzanych w systemie oświaty zwracano także uwagę na rolę szkoły, a zwłaszcza na szczególną funkcję nauczycieli i wychowawców w procesie kształcenia. Podkreślano również, że w owym procesie nie można pominąć wpływu środowiska (domu rodzinnego, organizacji np. harcerskiej, rówieśników, placówek pozaszkolnych) na ucznia lub studenta. Mimo że szkoła stanowi główne miejsce wychowania, to jednak „trzeba widzieć «ucznia» powiązanego gęstą siecią wzajemnych zależności z wszystkimi innymi kategoriami wychowawczych wpływów [...]”30. Odpowiedzialność za wychowanie młodych ludzi ponoszą i szkoła, i rodzice, i społeczeństwo, a redukowanie roli domu i nadmierna rozbudowa placówek i form pracy pozaszkolnej i opiekuńczo-wychowawczej nie są właściwe. „Szkoła w procesie wychowania wykonać może tylko swoją część zadań wyznaczonych jej programem dydaktyczno-wychowawczym, nie może natomiast zastępować rodziców w wypełnianiu ich rodzicielskich obowiązków. [...] rodzice winni wychowywać własnym przykładem, dbać o dobrą atmosferę wychowawczą życia rodzinnego"31.

To zagadnienie pojawiło się w przemówieniu ministra oświaty W. Bieńkowskiego, który stwierdził, że szkoła i sprawy z nią związane powinny „W większym niż dotychczas stopniu stać się ośrodkiem zainteresowania całego społeczeństwa. Od współdziałania ze szkołą, od opieki i pomocy udzielanej przez całe środowisko społeczne zależy w poważnej mierze rezultat jej pracy"32. Minister stwierdził, że należy dbać o podniesienie poziomu pracy szkół i udoskonalenie pracy wychowawczej, dlatego apelował do nauczycieli i pracowników oświaty, aby „wzmogli swój wysiłek nad doniosłym dziełem wychowania nowego pokolenia dziedziców i kontynuatorów naszej pracy i naszego dorobku"33. Podkreślał, że co roku państwo przeznacza coraz większe środki na budowę nowych szkół i poprawę warunków pracy nauczycieli. Świadczy to o docenianiu pracy tej grupy zawodowej i ,jest poważnym krokiem ku pełnemu społecznemu uznaniu [...] roli chorążych postępu, budowniczych socjalistycznej przyszłości"34.

Podobne przesłanie kierował do nauczycieli szkół wyższych premier J. Cyrankiewicz, mówiąc, iż „kształcenie specjalistów i jednocześnie wychowanie ideowych ludzi określa kierunek wysiłków [...] zarówno młodzieży, jak i profesury"35. Premier określił wprost misję kadry wykładowców uczelni wyższej, stwierdził, że powinna ona przekazywać wiedzę i wychowywać studentów, kształtować nawyki sumienności i systematyczności, wdrażać do samodzielnej pracy, aby

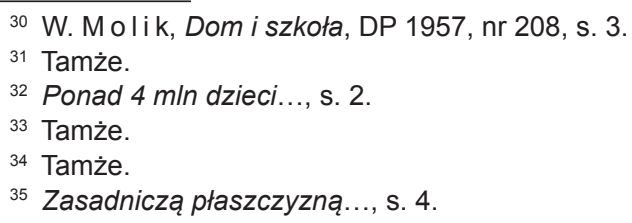


w przyszłości potrafili zmierzyć się z zacofaniem i zastojem w tych dziedzinach, w których będą pracować ${ }^{36}$.

W sprawozdaniach z inauguracji roku akademickiego 1958/1959 w wyższych uczelniach Krakowa ${ }^{37}$ znalazł się fragment wystąpienia doc. dr. Wincentego Danka, rektora Wyższej Szkoły Pedagogicznej. W swoim przemówieniu rektor bardzo wyraźnie określił funkcje, jakie musi spełnić uczelnia powstała „z konkretnych potrzeb szkoły polskiej”38 i kształcąca kadrę specjalistów dla potrzeb krajowego szkolnictwa. Za podstawowe uznał więc wychowanie studentów „w oparciu o świecki pogląd na świat, wszczepianie [...] umiłowania nauki i zawodu nauczycielskiego"39. O tej szczególnej misji krakowskiej uczelni wspominano także w „Dzienniku Polskim” z okazji rozpoczęcia roku akademickiego 1960/1961. Inauguracja 15. roku akademickiego była szczególnie uroczysta, z udziałem m.in. Wojciecha Pokory, dyrektora generalnego Ministerstwa Oświaty, który wskazał obowiązki „i rolę uczelni w związku z nadchodzącymi przemianami w szkolnictwie"40.

Na temat obowiązków nauczycieli i wychowawców wypowiedział się również Władysław Osiadacz, wiceprezes ZG ZNP41. Stwierdził, że „Związek Nauczycielstwa Polskiego przyjmuje na siebie zadanie stałego rozwoju działalności wychowawczej w kierunku kształtowania właściwej postawy ideowo-moralnej nauczyciela - entuzjasty i świadomego bojownika idei wychowania nowego człowieka na zasadach moralności socjalistycznej”42. Podkreślił jednak, że „obok [...] wysokich walorów ideowych - każdego nauczyciela cechować powinno odpowiednie przygotowanie zawodowe" 43 , a także umiejętność samokształcenia i dlatego „Związek Nauczycielstwa wraz z władzami oświatowymi prowadzi kształcenie drogą konferencji rejonowych w zakresie ogólnopedagogicznym i specjalistycznym, przedmiotowym. Mają one [...] rozbudzić ruch umysłowy wśród nauczycielstwa i przygotować właśnie do samokształcenia"44.

Na znaczenie kształcenia kadry nauczycieli, właściwego ich przygotowania i pełnienia roli wychowawców młodego pokolenia zwracano szczególną uwagę w związku z wprowadzaniem reformy systemu oświaty. Podkreślano, iż każdy z nauczycieli powinien stale podnosić swoje kwalifikacje, gdyż to on „decyduje i decydować będzie o wynikach pracy szkoły, o jej właściwym obliczu ideowo-wychowawczym, o postawie ideowej wychowanków" 45 . Reforma oświaty pogłębiała świeckie wychowanie młodzieży, co wymagało także intensyfikacji pracy ideowo-politycznej obejmującej kadrę nauczycielską. „Ostatnie lata zaznaczyły się wzrostem szeregów partyjnych w środowisku nauczycielskim, przy czym wśród

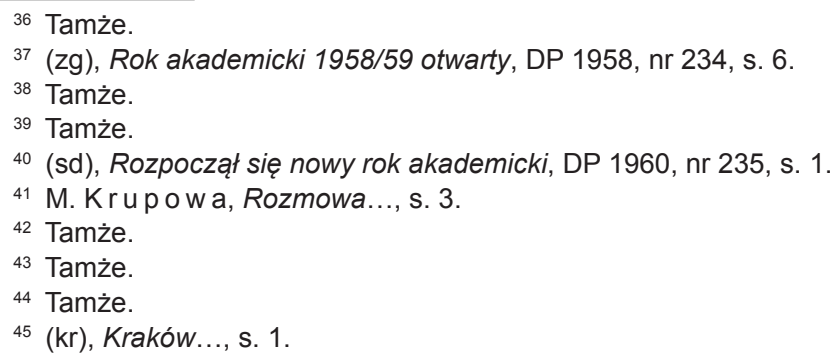


kandydatów do partii mamy wielu młodych nauczycieli. Jest to rękojmia pomyślnej realizacji wyznaczonych zadań w dziedzinie oświatowej"46.

„Dziennik Polski”, regionalne pismo o charakterze informacyjno-publicystycznym, informował swoich czytelników o kwestiach dotyczących szkolnictwa w Polsce w latach 1956-1961, o reformach i zmianach wprowadzanych w systemie oświaty, a także o nowej - w kontekście dokonywanych przemian - roli nauczycieli i wychowawców. W zamieszczanych tekstach prasowych zagadnienia te były poruszane albo w związku z rozpoczynającym się nowym rokiem szkolnym (akademickim), albo oddzielnie, jako informacje z obrad sejmu, sprawozdania z konferencji nauczycieli czy też wywiady z przedstawicielami ZNP. Znamiennym rysem publikacji prasowych $z$ tego okresu jest dominująca w nich opinia o konieczności wprowadzenia reform, uzasadniana hasłami „,budowy lepszej socjalistycznej przyszłości dla naszego narodu"47, podniesienia poziomu wiedzy i lepszego przygotowania zawodowego, ponieważ „w całym świecie trwa gigantyczny wyścig [...], w którym o zwycięstwie decyduje wiedza, technika i sprawność organizacyjna"48. W latach 1956-1961 „Dziennik Polski” był więc źródłem różnorodnych informacji o zmianach dokonujących się w polskim szkolnictwie.

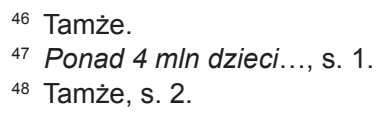

